\title{
SOME OF THE FACTORS WHICH AFFECT THE MEASURE- MENT OF SOUND ABSORPTION
}

\author{
By V. L. Chrisler and Catherine E. Miller
}

\section{ABSTRACT}

It has been found that air has an appreciable absorption for sound at frequencies as low as 512 cycles per second. This absorption varies with the temperature, the moisture content, and the barometric pressure. Curves are given showing such changes in absorption in the reverberation room at the Bureau of Standards.

Attention is called to the fact that when a highly absorbent sample is placed in a very reverberant room the decay curve may not be logarithmic.

Measurements of sound absorption on the same samples made by different observers in different reverberation rooms have in the past shown variations difficult to explain. Some of the factors responsible for these variations are now beginning to be recognized and understood. Humidity, temperature, and even barometric pressure have been found to cause quite perceptible changes in sound absorption measurements. P. E. Sabine ${ }^{1}$ first called attention to the fact that decreased humidity materially increased the absorption of an empty reverberation room for frequencies above 2,000 cycles. Later Knudsen ${ }^{2}$ described some pioneer work on this effect and determined coefficients for the sound absorption of air containing varying amounts of water vapor. Additional experimental work shows that not only humidity, but also temperature and pressure cause changes in the sound absorption of air.

For the most part the effect of these factors (in rooms of 10,000 to 20,000 cubic feet) is perceptible only at the higher frequencies of 1,000 cycles or more, but under favorable conditions this effect can be measured at 512 cycles. In large rooms of 1,000,000 cubic feet or more this effect should be noticeable at all frequencies.

These hitherto unexplained changes were noticed by us over two years ago and records of temperature, humidity, and pressure have been kept for the last year in the hope that a correlation would become evident. Knudsen's paper gave the first suggestion as to how the data might be interpreted. He determined the reverberation time of two rooms which had the same lining material but different volumes. The temperature in these two rooms was maintained approximately constant, but the relative humidity varied.

1 P. E. Sabine, The Measurement of Sound Absorption Coefficients, J. Franklin Inst., vol. 207, p. 347. 2 V. O. Knudsen, The Effect of Humidity upon the Absorption of Sound in a Room, and a Determination of the Coefficients of Absorption of Sound in Air, J. Acoustical Soc. Am., July, 1931. 
As a result of his investigation, Knudsen proposed that the customary formula for the reverberation time be written with a corrective term depending upon humidity, as follows:

where

$$
T=\frac{0.05 V}{-S \log _{e}(1-\alpha)+4 m V}
$$

$T=$ reverberation time,

$V=$ volume of room in cubic feet,

$S=$ surface in square feet,

$\alpha=$ average coefficient of sound absorption, and

$m$ is an attenuation constant, measuring the decay of the sound intensity with the distance traveled. The observed values of $T, S$, and $V$ were substituted in equation (1) thus obtaining two equations from which $a$ and $m$ were calculated.

In this way Knudsen determined $m$ for different relative humidities and at four different frequencies for temperatures between $21^{\circ}$ and $22^{\circ} \mathrm{C}$. It was found that a was a constant within the limits of experimental error, but that $m$ varied with the humidity.

To fit Knudsen's results to the present work, the assumption was made that the effect of water vapor on sound absorption of air depended solely upon vapor pressure and was independent of temperature and barometric pressure. On this basis Knudsen's curves for $m$, given in terms of relative humidity, were replotted in terms of vapor pressure and the corresponding values of $4 m V$ subtracted from the measured total absorption of our reverberation room. The residual absorption was then plotted against temperature. The scatter of these points suggested that Knudsen's values of $m$ did not adequately represent the effect of water vapor in our experiments. In addition, Knudsen's figures did not cover the full range of our vapor pressures. His curves were, therefore, modified by successive trial and error until the curves for residual absorption showed a minimum scatter of points from a smooth curve, the average variation being less than 1 per cent of the initial measured absorption and the maximum variation being only a little over 2 per cent.

The resulting empirical curves for $m$ at 2,048 and 4,096 cycles are shown in Figure 1 and the residual absorption-temperature curves in Figures 2 and 3.

The question of sound absorption of air has been considered theoretically by Rayleigh ${ }^{3}$ and others, and the conclusion was reached that the sound absorption should be proportional to the square of the frequency. This relation appears to hold good in the empirical curves for $m$ shown in Figure 1, as the value for $m$ at 4,096 cycles is four times that at 2,048 cycles. An exception to this is found when the vapor pressure is about 0.15 inch of mercury or less. Here the ratio seems to be about 3.9 .

In drawing the curves in Figures 2 and 3 the term $4 \mathrm{mV}$ was calculated from the curves in Figure 1 and subtracted from the measured total absorption. The remainder has hitherto been assumed to depend only on the absorption of the surface of the room, as indicated by its form $-S \log (1-a)$. But after correction has thus been made

Rayleigh, Theory of Sound, vol. 2, pp. 315-316. 


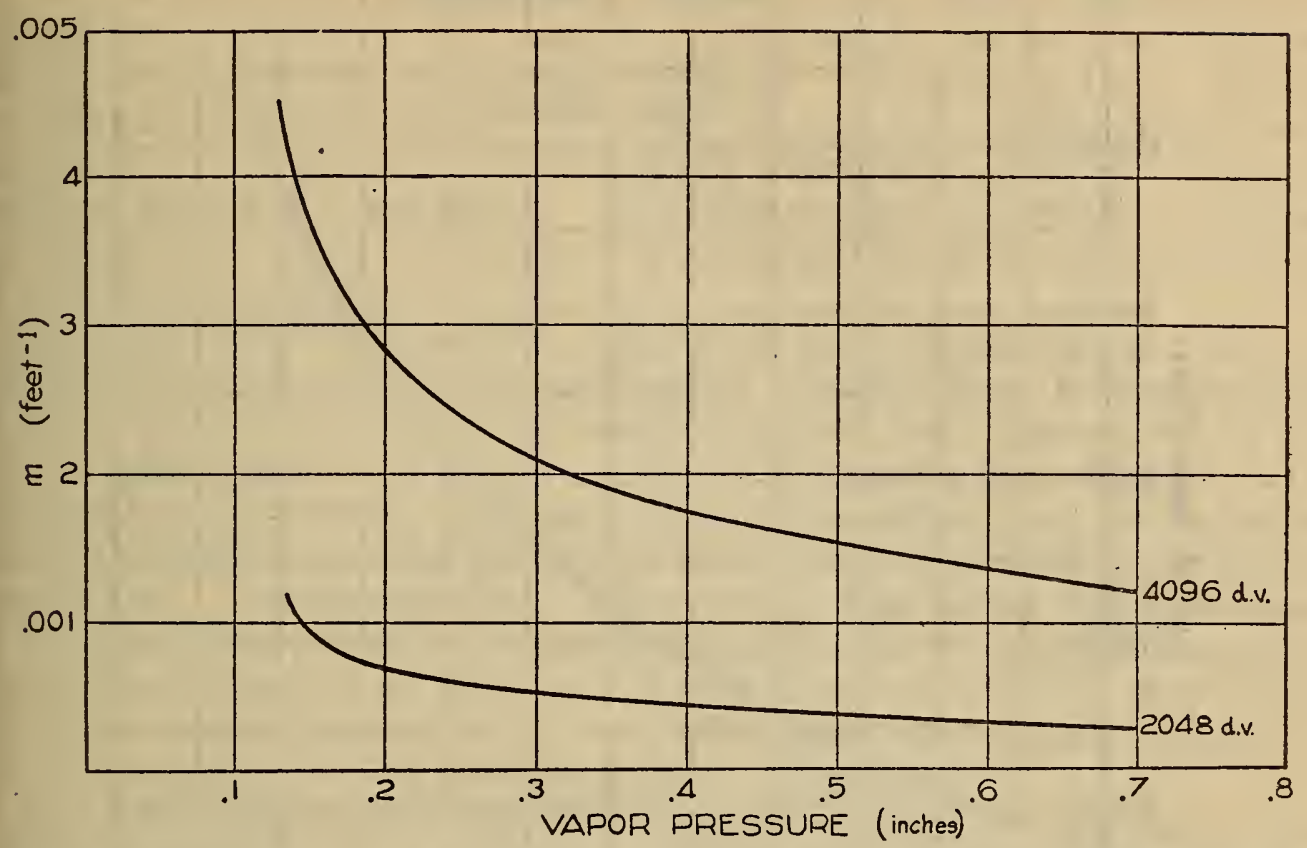

FIGURE 1.-Values of $m$ for air for different vapor pressures, at frequencies of 2,048 and 4,096 cycles

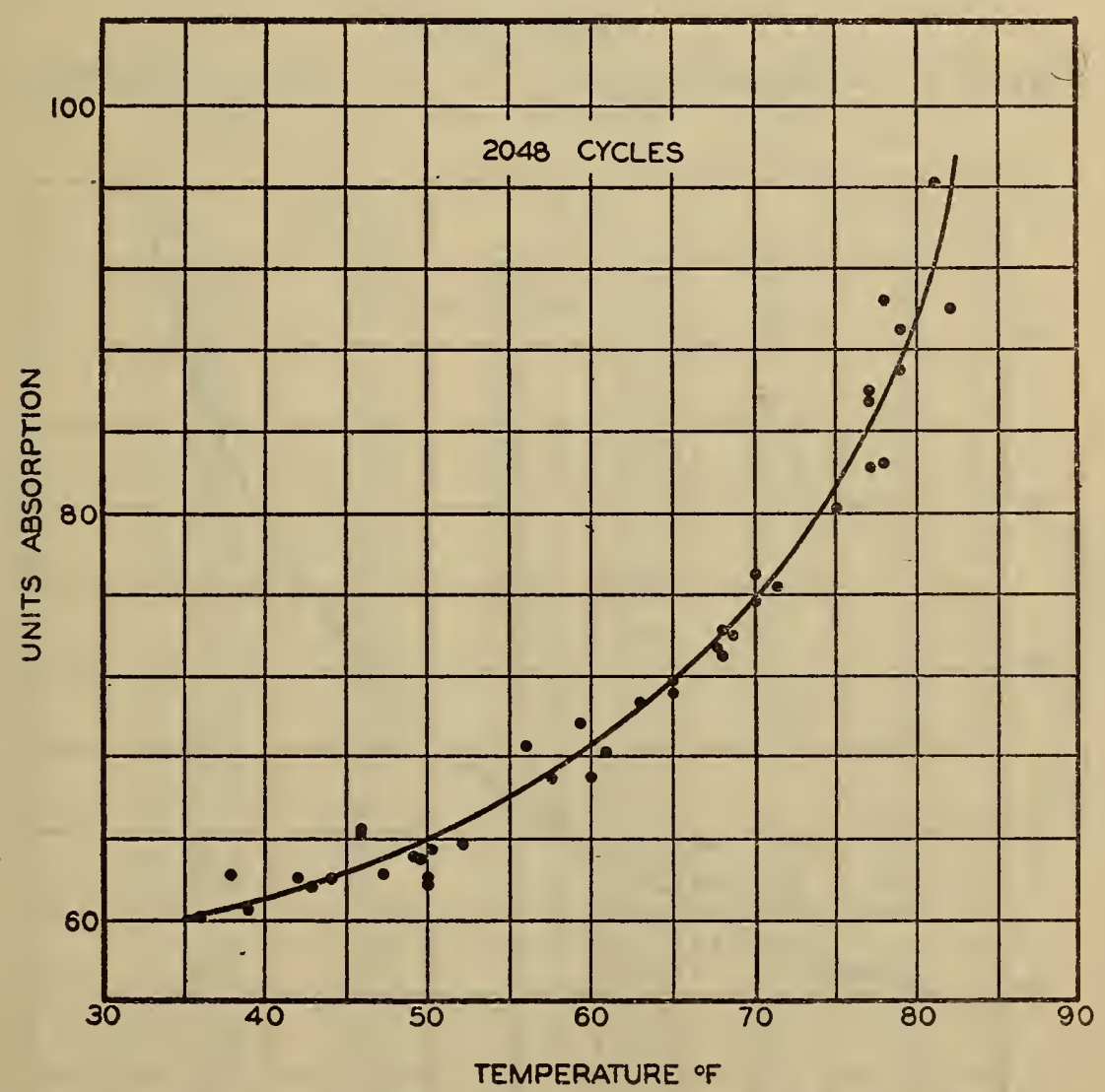

FIGURE 2.-Change of absorption of air with change of temperature at 2,048 cycles

$127984-32-5$ 


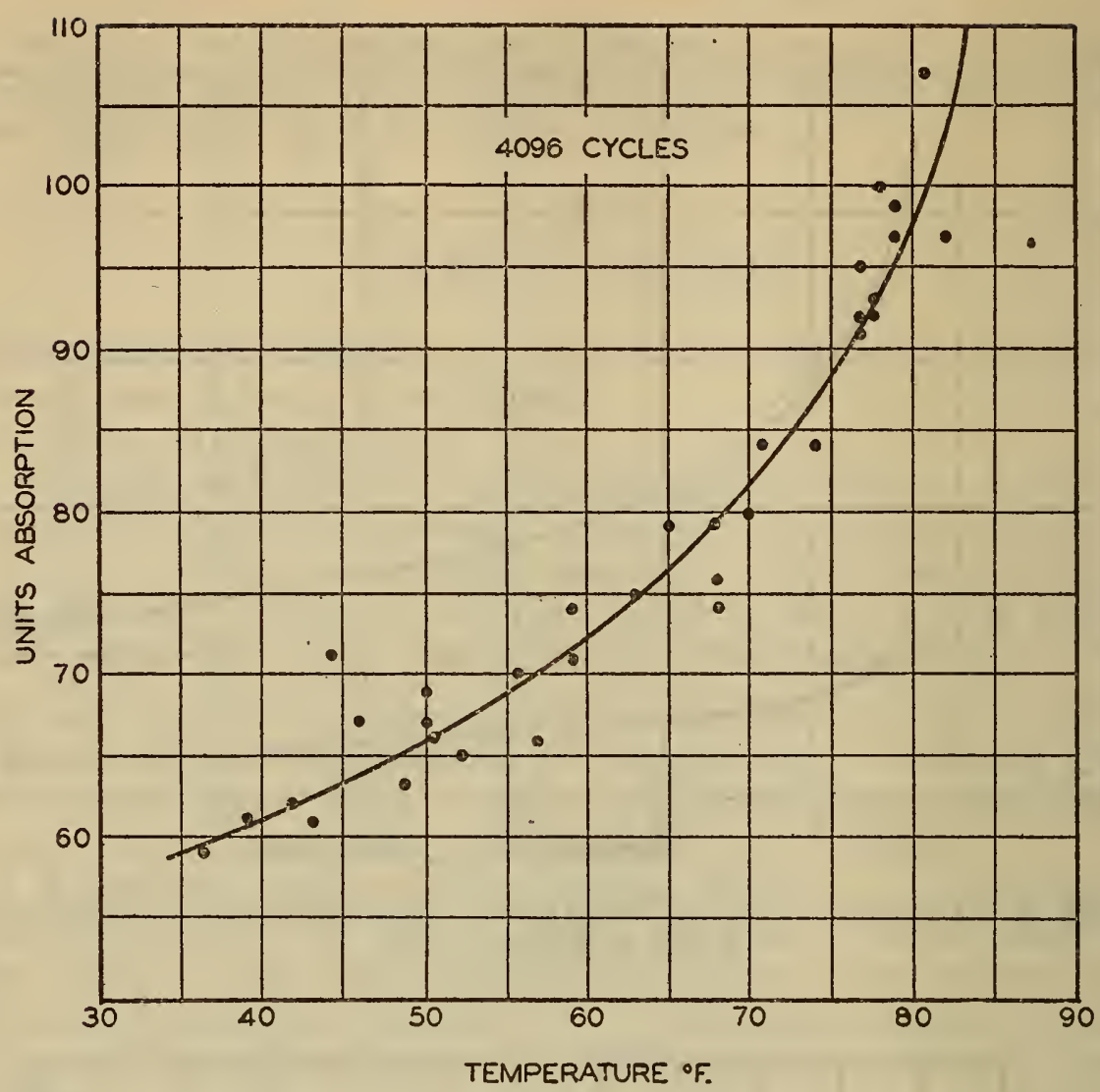

FIGURE 3.-Change of absorption of air with change of temperature at 4,096 cycles

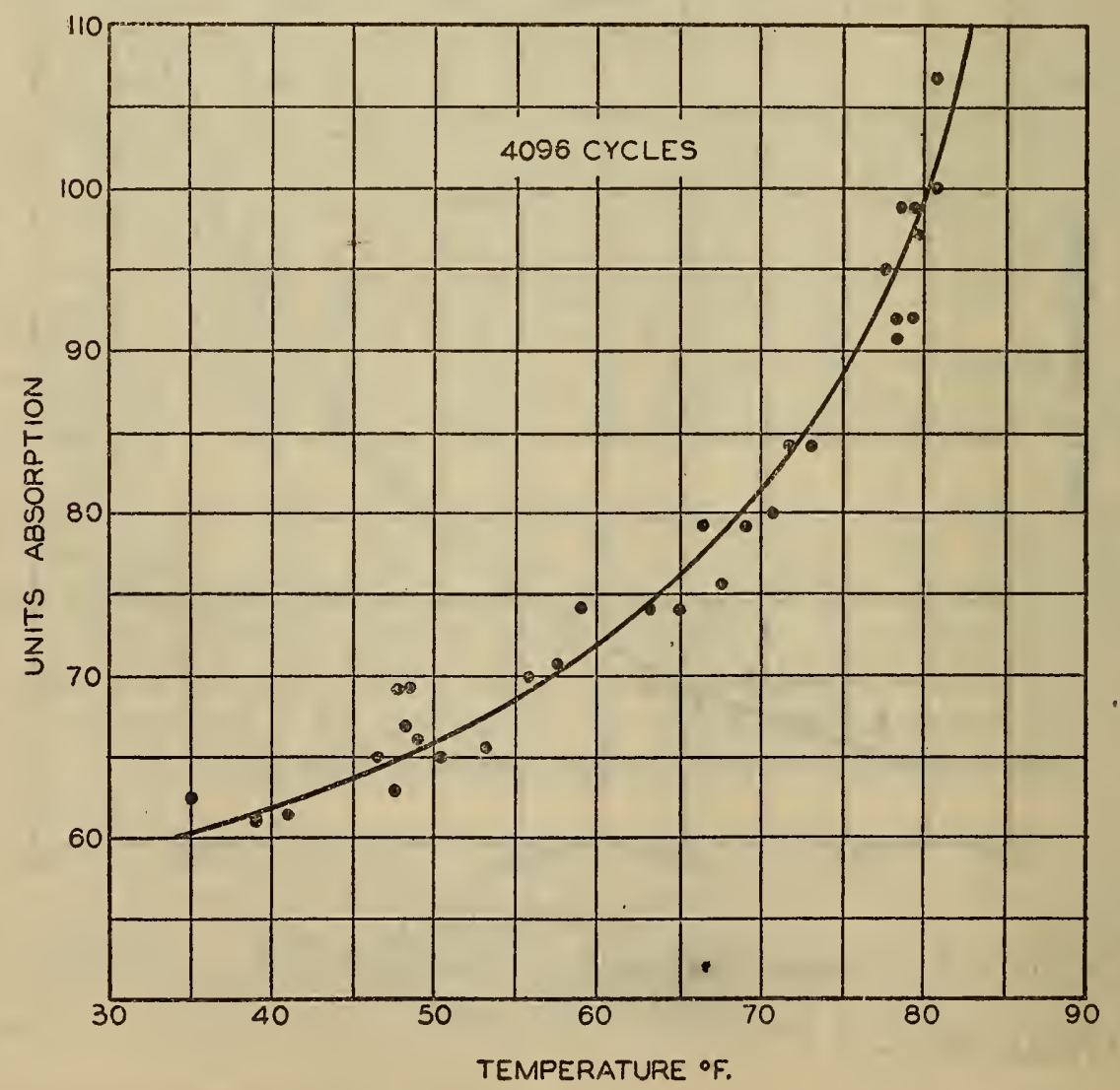

FIGURE 4.-Curve of Figure 3 corrected for changes in barometric pressure 
for water vapor, the absorption shows a very large variation with temperature, much more than can reasonably be ascribed to any change in absorption of the wall surfaces. It appears, then, that an additional correction must be made for the absorption of air as a function of temperature if a constant absorption coefficient for the walls of the room is assumed. That this surface absorption is practically independent of temperature is indicated by all measurements on absorbing materials.

On examining these curves, drawn so as to represent as fairly as possible the mean of the experimental observations, it was noticed that, in general, those points which departed from the curve on one side corresponded to higher barometric pressures than those on the other side of the curve. No theoretical explanation has been found for this fact, but it is possible to deduce from these deviations an empirical correction. For instance, at 4,096 cycles it was found that a decrease of 0.1 inch in barometric pressure has an effect on the sound absorption equivalent to that of an increase in temperature of $0.8^{\circ} \mathrm{F}$. Replotting: the curve with this empirical correction the experimental points fit much more closely to a smooth curve. (Fig. 4.)

At 2,048 cycles it is found that the same change in barometric pressure is equivalent to a change in temperature only one-fourth that with 4,096 cycles. For lower frequencies this correction becomes practically unimportant.

TABLE 1.-Corrections for water vapor at 2,048 cycles

\begin{tabular}{|c|c|c|c|c|c|}
\hline $\begin{array}{l}\text { Total } \\
\text { absorp- } \\
\text { tion }\end{array}$ & $\begin{array}{l}\text { Vapor } \\
\text { pressure }\end{array}$ & $m \times 10^{5}$ & $\begin{array}{l}\text { Correc- } \\
\text { tion for } \\
\text { water } \\
\text { vapor }\end{array}$ & $\begin{array}{c}\text { Total ab- } \\
\text { sorption } \\
\text { minus } \\
\text { correction }\end{array}$ & $\begin{array}{l}\text { Temper- } \\
\text { ature }\end{array}$ \\
\hline $\begin{array}{l}102.1 \\
101.7 \\
108.6 \\
105.2 \\
107.6\end{array}$ & $\begin{array}{c}\text { Inches } \mathrm{Hg} \\
0.54 \\
.69 \\
.68 \\
.62 \\
.67\end{array}$ & $\begin{array}{l}365 \\
303 \\
307 \\
331 \\
312\end{array}$ & $\begin{array}{l}21.7 \\
18.0 \\
18.2 \\
19.6 \\
18.5\end{array}$ & $\begin{array}{l}80.4 \\
83.7 \\
90.4 \\
85.6 \\
89.1\end{array}$ & $\begin{array}{l}\circ F \\
75 \\
77 \\
78 \\
77 \\
79\end{array}$ \\
\hline $\begin{array}{r}113.4 \\
107.5 \\
101.8 \\
95.0 \\
99.4\end{array}$ & $\begin{array}{l}.68 \\
.72 \\
.62 \\
.52 \\
.47\end{array}$ & $\begin{array}{l}307 \\
295 \\
331 \\
375 \\
400\end{array}$ & $\begin{array}{l}18.2 \\
17.5 \\
19.6 \\
22.2 \\
23.7\end{array}$ & $\begin{array}{l}95.2 \\
90.0 \\
82.2 \\
72.8 \\
75.7\end{array}$ & $\begin{array}{l}81 \\
82 \\
77 \\
68 \\
70\end{array}$ \\
\hline $\begin{array}{l}100.2 \\
104.4 \\
105.0 \\
104.7 \\
102.4\end{array}$ & $\begin{array}{l}.46 \\
.71 \\
.65 \\
.66 \\
.65\end{array}$ & $\begin{array}{l}403 \\
295 \\
320 \\
315 \\
320\end{array}$ & $\begin{array}{l}23.9 \\
17.5 \\
19.0 \\
18.7 \\
19.0\end{array}$ & $\begin{array}{l}76.3 \\
86.9 \\
86.0 \\
86.0 \\
83.4\end{array}$ & $\begin{array}{l}71 \\
79 \\
78 \\
77 \\
78\end{array}$ \\
\hline $\begin{array}{r}96.3 \\
102.0 \\
97.9 \\
98.7 \\
101.3\end{array}$ & $\begin{array}{l}.52 \\
.62 \\
.56 \\
.44 \\
.46\end{array}$ & $\begin{array}{l}375 \\
331 \\
356 \\
415 \\
403\end{array}$ & $\begin{array}{l}22.2 \\
19.6 \\
21.1 \\
24.6 \\
23.9\end{array}$ & $\begin{array}{l}74.1 \\
82.4 \\
76.8 \\
74.1 \\
77.4\end{array}$ & $\begin{array}{l}68 \\
74 \\
70 \\
68 \\
65\end{array}$ \\
\hline $\begin{array}{l}97.1 \\
96.6 \\
97.5 \\
96.2 \\
94.4\end{array}$ & $\begin{array}{l}.36 \\
.40 \\
.32 \\
.39 \\
.314\end{array}$ & $\begin{array}{l}467 \\
440 \\
504 \\
447 \\
510\end{array}$ & $\begin{array}{l}27.7 \\
26.1 \\
29.9 \\
26.6 \\
30.6\end{array}$ & $\begin{array}{l}69.4 \\
70.5 \\
68.6 \\
69.6 \\
63.8\end{array}$ & $\begin{array}{l}59 \\
63 \\
56 \\
59 \\
52\end{array}$ \\
\hline $\begin{array}{r}94.0 \\
94.9 \\
98.3 \\
102.6 \\
102.9\end{array}$ & $\begin{array}{l}.298 \\
.278 \\
.251 \\
.200 \\
.228\end{array}$ & $\begin{array}{l}540 \\
552 \\
593 \\
690 \\
630\end{array}$ & $\begin{array}{l}32.1 \\
32.8 \\
35.3 \\
41.0 \\
37.4\end{array}$ & $\begin{array}{l}61.9 \\
62.1 \\
63.0 \\
61.6 \\
65.5\end{array}$ & $\begin{array}{l}50 \\
50 \\
49 \\
43 \\
44.5\end{array}$ \\
\hline $\begin{array}{r}103.2 \\
96.6 \\
102.2 \\
106.3\end{array}$ & $\begin{array}{l}.213 \\
.273 \\
.223 \\
.173\end{array}$ & $\begin{array}{l}660 \\
560 \\
640 \\
705\end{array}$ & $\begin{array}{l}39.2 \\
33.3 \\
38.0 \\
41.9\end{array}$ & $\begin{array}{l}64.0 \\
63.3 \\
64.2 \\
62.2\end{array}$ & $\begin{array}{l}45 \\
50.5 \\
46 \\
44\end{array}$ \\
\hline $\begin{array}{l}102.5 \\
129.5 \\
113.6 \\
114.6\end{array}$ & $\begin{array}{l}.204 \\
.134 \\
.153 \\
.159\end{array}$ & $\begin{array}{r}680 \\
1,160 \\
905 \\
880\end{array}$ & $\begin{array}{l}40.4 \\
68.9 \\
53.8 \\
52.3\end{array}$ & $\begin{array}{l}62.1 \\
60.6 \\
59.8 \\
62.3\end{array}$ & $\begin{array}{l}42 \\
39 \\
36.3 \\
37.5\end{array}$ \\
\hline
\end{tabular}


TABLE 2.-Corrections for water vapor at 4,096 cycles

\begin{tabular}{|c|c|c|c|c|c|c|}
\hline $\begin{array}{l}\text { Total } \\
\text { absorp- } \\
\text { tion }\end{array}$ & $\begin{array}{l}\text { Vapor } \\
\text { pressure }\end{array}$ & $m \times 10^{5}$ & $\begin{array}{l}\text { Correc- } \\
\text { tion for } \\
\text { water } \\
\text { vapor }\end{array}$ & $\begin{array}{l}\text { Total ab- } \\
\text { sorption } \\
\text { minus } \\
\text { correction }\end{array}$ & $\begin{array}{c}\text { Observed } \\
\text { tempera- } \\
\text { ture }\end{array}$ & $\begin{array}{l}\text { Correct- } \\
\text { ed tem- } \\
\text { perature }\end{array}$ \\
\hline $\begin{array}{l}163 \\
173 \\
173 \\
173 \\
179\end{array}$ & $\begin{array}{c}\text { Inches } \mathrm{Hg} \\
0.69 \\
.68 \\
.62 \\
.67 \\
.69\end{array}$ & $\begin{array}{l}121 \\
122 \\
132 \\
124 \\
121\end{array}$ & $\begin{array}{l}72 \\
73 \\
78 \\
74 \\
72\end{array}$ & $\begin{array}{r}91 \\
100 \\
95 \\
99 \\
107\end{array}$ & $\begin{array}{l}\circ F . \\
77 \\
78 \\
77 \\
79 \\
81\end{array}$ & $\begin{array}{l}{ }^{\circ} F . \\
78.3 \\
81 \\
77.5 \\
79.6 \\
80.7\end{array}$ \\
\hline $\begin{array}{l}167 \\
170 \\
168 \\
176 \\
180\end{array}$ & $\begin{array}{l}.71 \\
.62 \\
.52 \\
.47 \\
.46\end{array}$ & $\begin{array}{l}118 \\
132 \\
150 \\
161 \\
162\end{array}$ & $\begin{array}{l}70 \\
78 \\
89 \\
96 \\
96\end{array}$ & $\begin{array}{l}97 \\
92 \\
79 \\
80 \\
84\end{array}$ & $\begin{array}{l}82 \\
77 \\
68 \\
70 \\
71\end{array}$ & $\begin{array}{l}79.8 \\
78.4 \\
68.7 \\
70.8 \\
71.8\end{array}$ \\
\hline $\begin{array}{l}168 \\
167 \\
165 \\
168 \\
165\end{array}$ & $\begin{array}{l}.71 \\
.65 \\
.66 \\
.65 \\
.52\end{array}$ & $\begin{array}{l}118 \\
127 \\
125 \\
127 \\
150\end{array}$ & $\begin{array}{l}70 \\
75 \\
74 \\
75 \\
89\end{array}$ & $\begin{array}{l}98 \\
92 \\
91 \\
93 \\
76\end{array}$ & $\begin{array}{l}79 \\
78 \\
77 \\
78 \\
68\end{array}$ & $\begin{array}{c}79 \\
78.9 \\
67 .\end{array}$ \\
\hline $\begin{array}{l}162 \\
168 \\
172 \\
174 \\
182\end{array}$ & $\begin{array}{l}.62 \\
.56 \\
.45 \\
.46 \\
.36\end{array}$ & $\begin{array}{l}132 \\
143 \\
165 \\
162 \\
186\end{array}$ & $\begin{array}{r}78 \\
85 \\
98 \\
96 \\
111\end{array}$ & $\begin{array}{l}84 \\
83 \\
74 \\
78 \\
71\end{array}$ & $\begin{array}{l}74 \\
70 \\
68 \\
65 \\
59\end{array}$ & $\begin{array}{l}73.1 \\
68.4 \\
65.4 \\
66.4 \\
57.7\end{array}$ \\
\hline $\begin{array}{l}179 \\
189 \\
180 \\
185 \\
172\end{array}$ & $\begin{array}{l}.40 \\
.32 \\
.39 \\
.314 \\
.387\end{array}$ & $\begin{array}{l}176 \\
200 \\
178 \\
202 \\
179\end{array}$ & $\begin{array}{l}105 \\
119 \\
106 \\
120 \\
106\end{array}$ & $\begin{array}{l}74 \\
70 \\
74 \\
65 \\
66\end{array}$ & $\begin{array}{l}63 \\
56 \\
59 \\
52 \\
56.8\end{array}$ & $\begin{array}{l}63 \\
56.2 \\
58.7 \\
50.4 \\
53.3\end{array}$ \\
\hline $\begin{array}{l}195 \\
201 \\
205 \\
228\end{array}$ & $\begin{array}{l}.289 \\
.278 \\
.251 \\
.200\end{array}$ & $\begin{array}{l}216 \\
222 \\
239 \\
281\end{array}$ & $\begin{array}{l}128 \\
132 \\
142 \\
167\end{array}$ & $\begin{array}{l}67 \\
69 \\
63 \\
61\end{array}$ & $\begin{array}{l}50 \\
50 \\
49 \\
43\end{array}$ & $\begin{array}{l}49.1 \\
47.9 \\
48.1 \\
38.7\end{array}$ \\
\hline $\begin{array}{l}221 \\
225 \\
200 \\
222\end{array}$ & $\begin{array}{l}.228 \\
.213 \\
.273 \\
.223\end{array}$ & $\begin{array}{l}256 \\
269 \\
226 \\
260\end{array}$ & $\begin{array}{l}152 \\
160 \\
134 \\
155\end{array}$ & $\begin{array}{l}69 \\
65 \\
66 \\
67\end{array}$ & $\begin{array}{l}44.5 \\
45 \\
50.5 \\
46\end{array}$ & $\begin{array}{l}48.1 \\
46.6 \\
53 \\
48.4\end{array}$ \\
\hline $\begin{array}{l}227 \\
313 \\
269\end{array}$ & $\begin{array}{l}.204 \\
.134 \\
.159\end{array}$ & $\begin{array}{l}273 \\
424\end{array}$ & $\begin{array}{l}165 \\
250\end{array}$ & $\begin{array}{l}62 \\
63 \\
62\end{array}$ & $\begin{array}{l}42 \\
39\end{array}$ & 40.9 \\
\hline & & 346 & 206 & & 37.5 & 35.1 \\
\hline
\end{tabular}

The original measurements at 2,048 and 4,096 cycles, and the corrections made for the moisture content of the air are shown in Tables 1 and 2 . In Table 2 the corrected temperature in the last column is obtained from the observed temperature by applying the above-mentioned change of temperature empirically equivalent to the variation in barometric pressure. This correction at 2,048 cycles is quite small and has been neglected in Table 1.

Figure 5 shows the relation between $m$ and vapor pressure for 1,024 and 512 cycles and Figures 6 and 7 show the corresponding absorptiontemperature curves. These curves were calculated from the curves for 2,048 and 4,096 cycles by Rayleigh's law and fitted the data so well that no further empirical adjustment was made.

One of the most striking illustrations of the use of these curves occurred on a day of cold, windy weather in Washington in March, 1932. It has been our custom to measure the absorption of the empty room either immediately before or immediately after the measurements on the sample of the material. On this particular day the measurements were made on the sample first. As soon as the sample was removed from the room, measurements were made of the 
absorption of the empty room at 2,048 and 4,096 cycles. Much to our surprise it was found that at 4,096 cycles the empty room had more absorption than when it contained the sample.

By referring to the wet and dry bulb thermometer measurements made before and after the sample was removed it was found that there had been a considerable change in the humidity and a very small change in temperature, caused by the high wind changing the air in the room while the door was opened for removing the sample. When corrections taken from the curves of Figures 1, 2, and 3 were made for the changes in humidity and temperature, the sample was found to have a reasonable degree of absorption. On a later day when conditions (in respect to humidity and temperature) were approximately the same inside and outside the reverberation room, measurements were repeated on this same sample, and the coefficients

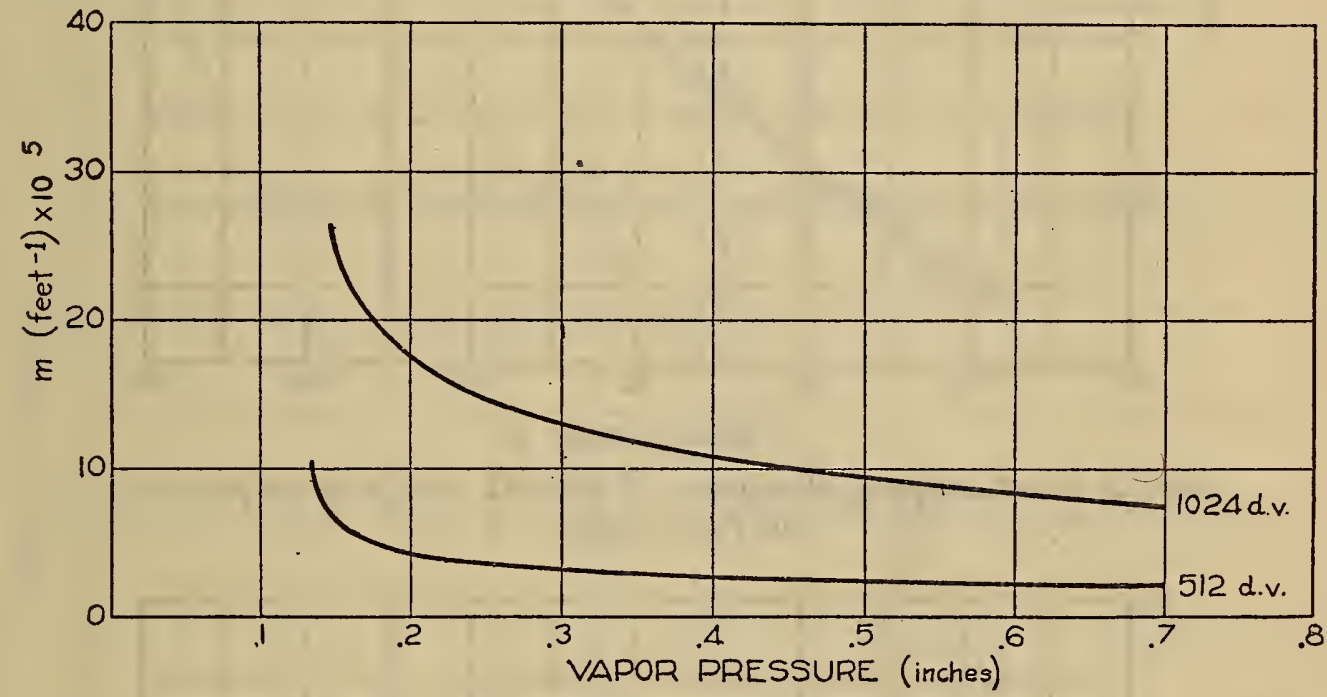

FIgURE 5.-Values of $m$ for different conditions of vapor pressure, for frequencies of 512 and 1,024 cycles

of absorption which were obtained were found to agree almost exactly with those previously found.

The fact that air may have considerable absorption for sound is of interest in other fields. For instance, the distance that sound signals can be heard is of vital importance to shipping. Until quite recently it was thought that wind direction and velocity, layers of air of different densities which might cause reflection and refraction, and noise due to a storm were the principal factors which affected the distance at which a sound signal could be heard. More recent work shows that both temperature and humidity are important factors. Horner ${ }^{4}$ gives some of the results of a study in which it was found that the distance at which a sound signal might be heard depends upon the humidity and the temperature of the air. He states that when the humidity is high, distant sounds can be heard with abnormal loudness, while under very low humidity these same sounds may become completely inaudible. He also stated "the worst acoustical conditions were almost invariably found in the type of weather commonly known as oppressive." Here the temperatures were high and evidently the increased absorption due to the high temperature was the predominating factor.

1 Horner, Effect of Meteorological Condition on Sound Transmission at Sea, Nautical J., 1927. 


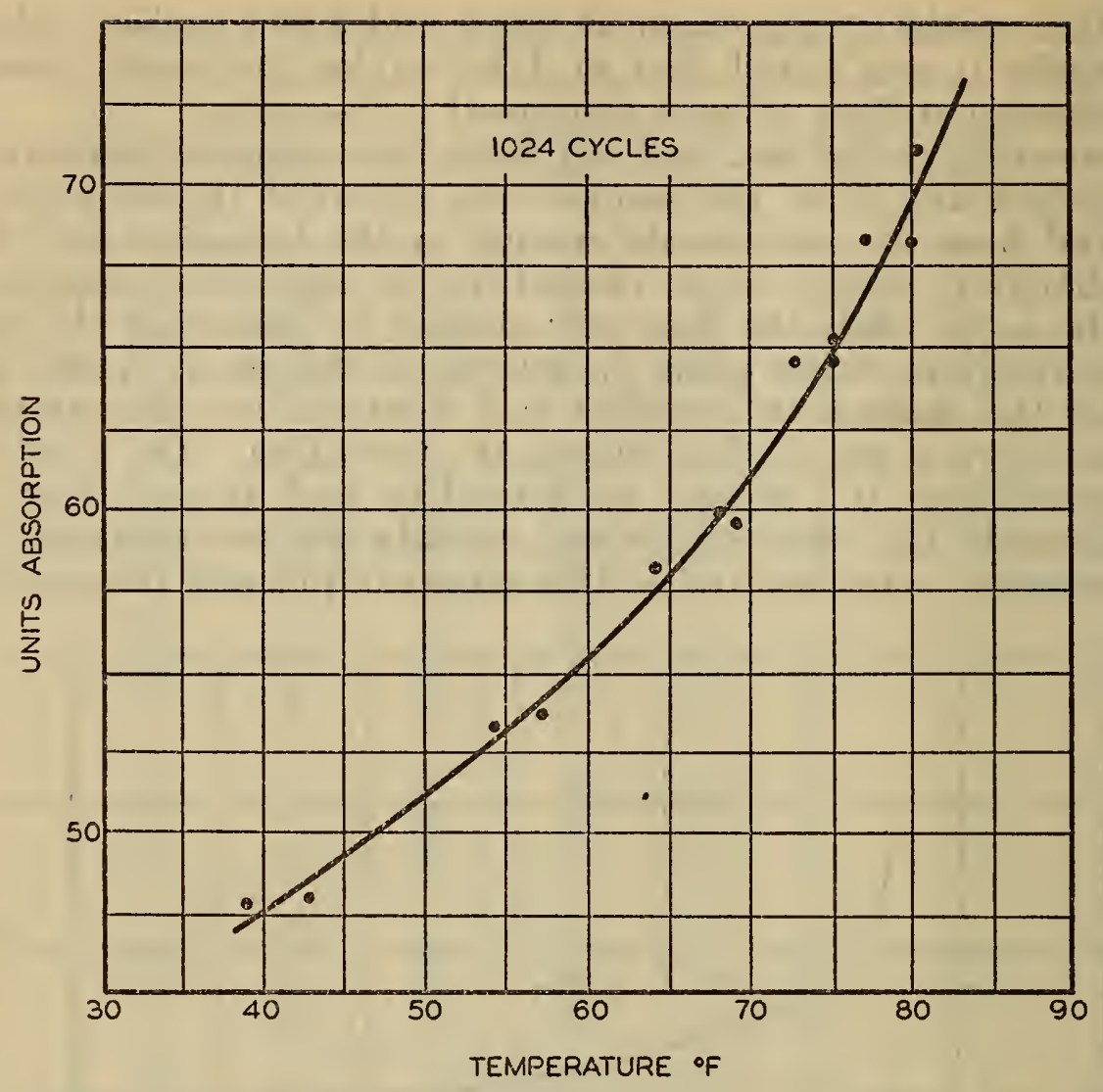

FigURE 6.-Change of absorption of air with change of temperature at 1,024 cycles

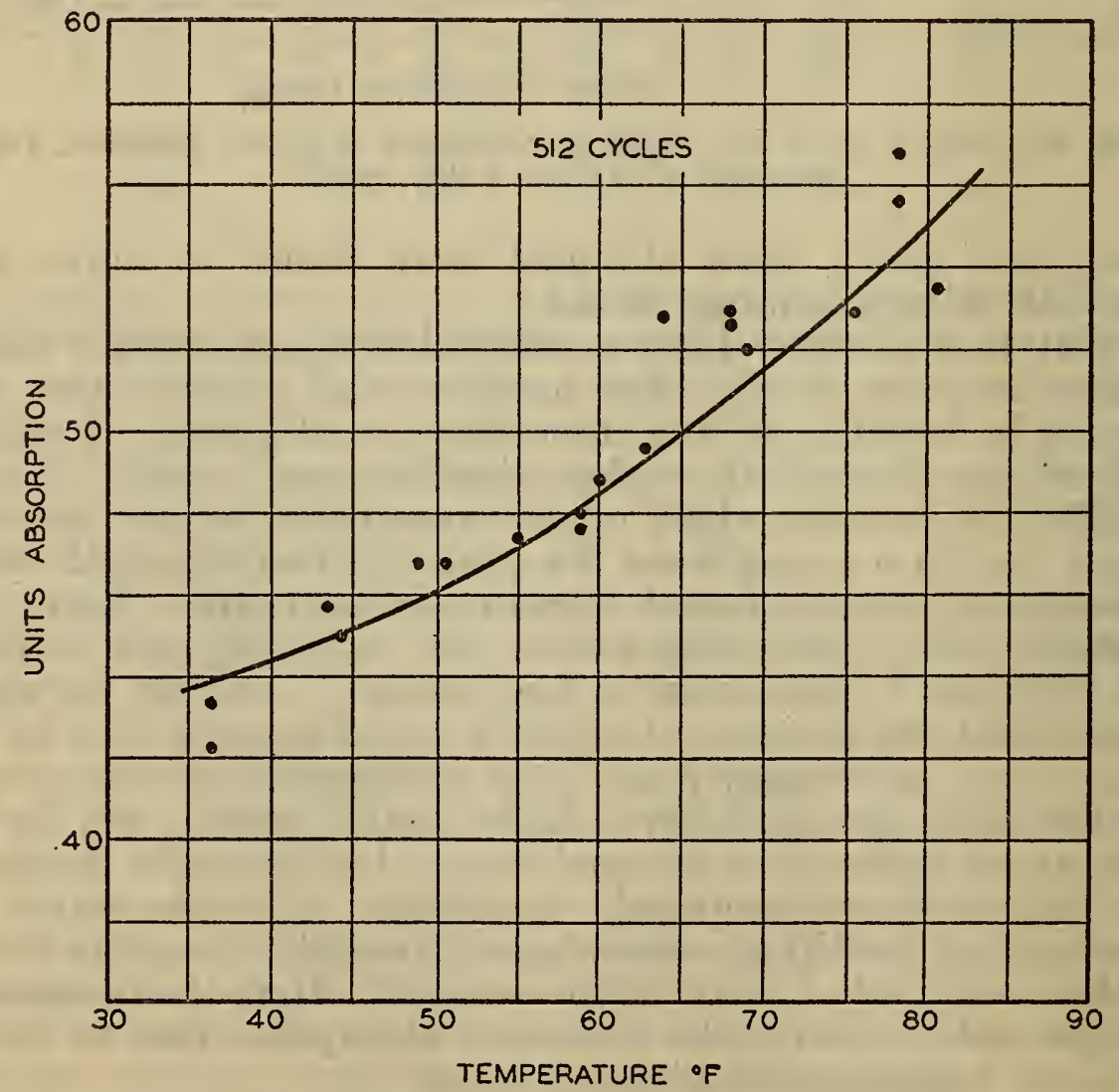

FIgURE 7.-Change of absorption of air with change of temperature at 512 cycles 
Recent measurements made near Boston by the Lighthouse Service also show some interesting facts. A comparison was being made between a siren and an electric oscillator. In both cases the fundamental note was about 180 cycles per second. A considerable percentage of the energy of the siren was in overtones while the electric oscillator gave practically a pure note. When the observer was close the siren sounded the louder, but at a distance of 2 or 3 miles the oscillator was the louder, showing that the air has considerably less absorption for low-pitched notes.

In all sound-absorption measurements the assumption has heretofore been made that the decay of sound energy in a reverberation

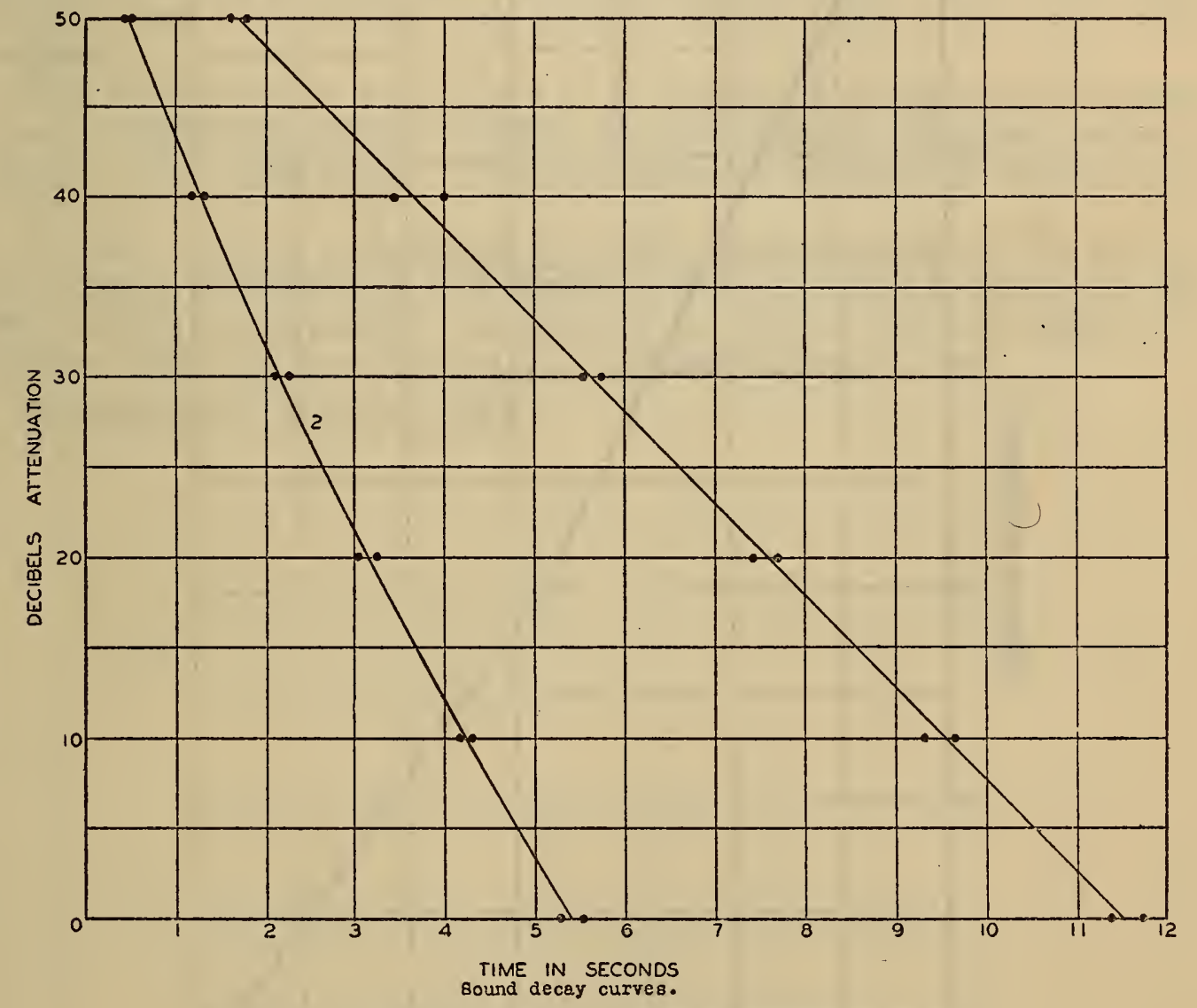

1, empty room.

FIGURE 8.-Sound-decay curves

2, highly absorbent sample in room.

room is logarithmic. With improved methods of measurement now available it is possible to determine the form of the decay curve with considerable accuracy. Figure 8 shows the decay curve at 1,024 cycles plotted logarithmically, for an empty reverberation room and for the same room containing a highly absorbent sample of material. With the sample in the room it will be noticed that the rate of decay is not uniform.

In the case of curve 2 of Figure 8, while the rate of decay is variable it shows no sudden change. In another case, illustrated in Figure 9, the distribution of the observed points is fitted more closely by a broken line than by a smooth curve.

Since the slope of the decay curve is dependent in part upon the absorption of the sample, it might be supposed from the form of 
curve 2 (fig. 8) and of the curve in Figure 9 that the coefficient of absorption of the sample varied with the intensity of the sound; but by repeating the experiment of Figure 9 , starting from an initial level of sound intensity some 20 or $30 \mathrm{db}$ lower, it is found that the knee is not fixed in position, but suffers a corresponding shift downward. We must, therefore, conclude that the change in slope is not due to change in coefficient with the intensity of the sound, but is rather to be ascribed to nonuniform distribution of the sound energy. Considerations of conditions in the reverberation room indicate that

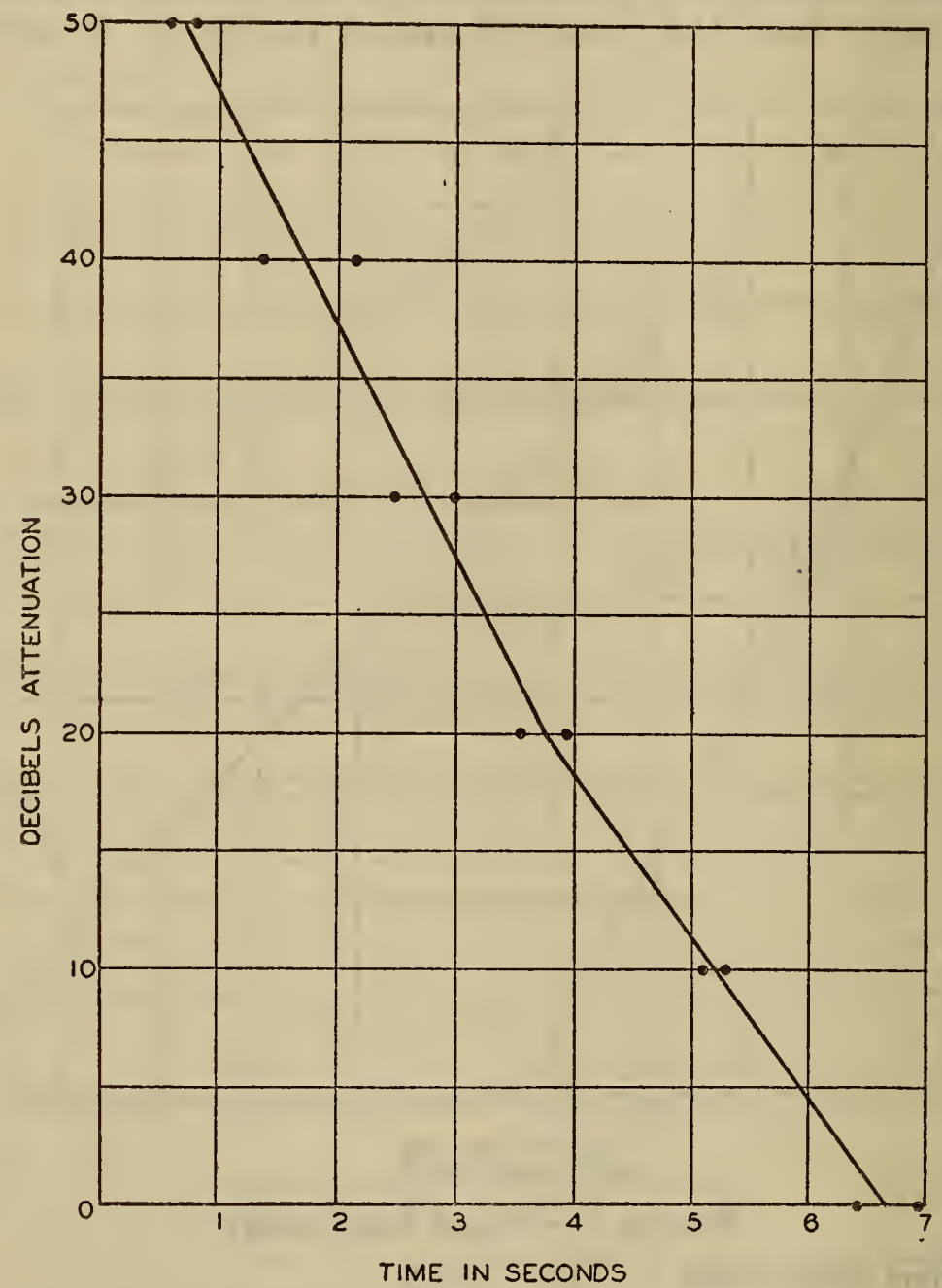

FIGURE 9.-Sound-decay curve with a sample of highly absorbent material in the reverberation room

this is the probable explanation. In the empty room the absorption coefficient of the walls, etc., is only about 1 per cent, and is approximately uniform over the whole interior, but when a sample of highly absorbent material is placed in the room the rate of absorption over the surface of this sample may be 60 or more times as great as over the wall surfaces. Moreover, this sample is usually of an area which is not negligible as compared to the boundaries of the room.

The source of sound is designed so as to give as nearly as possible a a uniform initial distribution of sound energy in the room, but after the source has been stopped the extreme heterogeneity of absorption present makes it probable that the distribution of sound energy does not remain uniform as it decays. 
The question then arises as to how the absorption should be calculated, as in all reverberation methods a straight line decay has been assumed. If the reason advanced above for the change of slope is correct, the slope of the initial portion of the curve would give the better value for the absorption. With a curve of varying slope the ear method, necessarily involving the whole curve, is incapable of giving correct results, as it measures only the average slope of the whole curve.

\section{SUMMARY}

The total absorption of a room appears to depend upon the amount of water vapor present and upon the temperature. The calibration of the room is therefore not definite unless these factors are kept constant.

The coefficient of absorption of a sample of material will depend upon whether the initial, average, or final slope of the decay curve is used in the calculation. The ear method necessarily employs an average.

It may now be recognized that the determination of the soundabsorption coefficient of a material is not as simple a matter as has been hitherto supposed, but appears to depend upon a number of factors which are now beginning to be understood.

Washington, May 20, 1932. 